\title{
Identification of a novel 2026G $\rightarrow$ C mutation of the MRP2 gene in a Japanese patient with Dubin-Johnson syndrome
}

Received: 15 May 2003/ Accepted: 18 June 2003/Published online: 22 July 2003

(C) The Japan Society of Human Genetics and Springer-Verlag 2003

\begin{abstract}
Dubin-Johnson syndrome is a recessive inherited disorder with conjugated hyperbilirubinemia caused by a dysfunction of multidrug resistance protein 2 (MRP2) on the canalicular membrane of hepatocytes. A mutational analysis of the MRP2 gene was carried out in three Japanese patients and their family members. In two patients, the homozygous mutations c.1901del67 and c,2272del168 were found. In the third patient, a $-24 \mathrm{C} \rightarrow \mathrm{T}$ polymorphism and the two mutations c.1901del67 and 2026G $\rightarrow \mathrm{C}$ were detected. The $2026 \mathrm{G} \rightarrow \mathrm{C}$ mutation was a novel mutation in exon 16 affecting the conversion of Gly ${ }^{676}$ to $\mathrm{Arg}^{676}$ (G676R) in the MRP2 protein, and was not detected in fifty healthy volunteers. The G676R mutation was located in the Walker A motif of the first nucleotide binding domain in the MRP2 protein, and it was suggested that the mutation induced the dysfunction of the MRP2 protein. It was concluded that the compound heterozygosity of the two mutations of the MRP2 gene in the third patient contributed to the induction of hyperbilirubinemia in this case.
\end{abstract}

Keywords Dubin-Johnson syndrome $\cdot$ Multidrug resistance 2 (MRP2) · ATP-binding cassette · Walker A motif $\cdot$ Mutation

S. Wakusawa $(\bowtie) \cdot$ I. Machida $\cdot$ S. Suzuki $\cdot$ H. Hayashi Department of Medicine,

Faculty of Pharmaceutical Sciences, Hokuriku University, Ho-3, Kanagawa-machi, Kanazawa 920-1181, Japan

E-mail: s-wakusawa@hokuriku-u.ac.jp

Tel.: + 81-76-2296204

Fax: $+81-76-2296203$

M. Yano $\cdot$ K. Yoshioka

Gastroenterology, Nagoya University School of Medicine, Nagoya, Japan

\section{Introduction}

Dubin-Johnson syndrome (DJS) is an inherited metabolic disorder characterized by conjugated hyperbilirubinemia and a re-increase of serum bromosulfophtalein (BSP) in the BSP tolerance test, characteristics that are caused by a dysfunction of the canalicular multispecific anion transporter (cMOAT, multidrug resistance protein 2; MRP2).

The human MRP2 gene was identified in cisplatinresistant tumor cells by Taniguchi et al. (1996) following the identification of the rat cmoat (mrp2) gene in hyperbilirubinemia rats $\left(\mathrm{TR}^{-}\right.$rats) by Paulusma et al. (1996). The human MRP2 gene was mapped to chromosome 10 at q24 (Taniguchi et al. 1996) and was found to consist of 32 exons (Toh et al. 1999).

MRP2 protein is a membrane protein with 1545 amino acids; it contains two ATP-binding cassettes (ABCs) and 17 transmembrane sequences (Taniguchi et al. 1996). It is expressed at the canalicular membrane of hepatocytes and apical membrane of the renal uriniferous tuble (Paulusma et al.1996) and is involved in the excretion of glucronide-conjugated bilirubin and glutathione-conjugates from the liver (Taniguchi et al. 1996; Wada et al. 1998).

The first mutation of the MRP2 gene causing hyperbilirubinemia was found by Paulusma et al. (1997) in DJS, and a total of 10 mutations have been found as listed in Table 1.

In the present study, we conducted a mutational analysis in three Japanese DJS patients and found two known deletion mutations (c.1901del67, c.2272del168) and a novel missense mutation of G676R in the first nucleotide-binding domain (NBD1) in the MRP2 protein.

\section{Subjects and methods}

Study participants

Three DJS patients and their family members were included in the present study. 
Table 1 Mutations of MRP2 in Dubin-Johnson syndrome (DJS)

\begin{tabular}{|c|c|c|}
\hline Nucleotide mutation & Predicted effects & References \\
\hline \multicolumn{3}{|l|}{ Splice site mutation } \\
\hline $1815+2 \mathrm{~T} \rightarrow \mathrm{A}$ & $\begin{array}{l}\text { 1669del147 } \\
\text { (exon13 skipping) }\end{array}$ & Wada et al. 1998 \\
\hline $1967+2 \mathrm{~T} \rightarrow \mathrm{C}$ & $\begin{array}{l}1901 \text { del67 } \\
\text { (exon15 skipping) }\end{array}$ & Kajihara et al. 1998 \\
\hline $2439+2 \mathrm{~T} \rightarrow \mathrm{C}$ & $\begin{array}{l}\text { 2272del168 } \\
\text { (exon18 skipping) }\end{array}$ & Toh et al. 1999 \\
\hline $\begin{array}{l}\text { Deletion mutation } \\
\text { Del4170-5 }\end{array}$ & Del $\mathrm{R}^{1392}, \mathrm{M}^{1393}$ & Tsujii et al. 1999 \\
\hline \multicolumn{3}{|l|}{ Missense mutation } \\
\hline $2302 \mathrm{C} \rightarrow \mathrm{T}$ & R768 W & Wada et al. 1998 \\
\hline $3449 \mathrm{G} \rightarrow \mathrm{A}$ & $\mathrm{R} 1150 \mathrm{H}$ & Mor-Cohen et al. 2001 \\
\hline $3517 \mathrm{~A} \rightarrow \mathrm{T}$ & I1173F & Mor-Cohen et al. 2001 \\
\hline $4145 \mathrm{~A} \rightarrow \mathrm{G}$ & Q1382R & Toh et al. 1999 \\
\hline \multicolumn{3}{|l|}{ Nonesense mutation } \\
\hline $3196 \mathrm{C} \rightarrow \mathrm{T}$ & R1066X & Paulusma et al. 1997 \\
\hline $3928 \mathrm{C} \rightarrow \mathrm{T}$ & R1310X & Tate et al. 2002 \\
\hline
\end{tabular}

Patient 1 (DJ1) was a male whose parents were distantly related. He was diagnosed with DJS at the age of 28 years based on hyperbilirunemia, a BSP test, and a histological examination of the liver. Serum bilirubin values of his two daughters and spouse were within the normal range.

Patient 2 (DJ2) was a female whose parents were the first cousins. She was diagnosed with DJS at the age of 23 years based on hyperbilirunemia, a BSP test, and a histological examination of the liver. Serum bilirubin values of her two siblings, daughter, and spouse were within the normal range.

Patient 3 (DJ3) was a male whose parents were distantly related. He was diagnosed with chronic hepatitis and DJS at the age of 25 years based on serum aminotransferase levels, conjugated hyperbilirunemia, a BSP test, and a histological examination of the liver. Thereafter, he was diagnosed as having DJS with chronic hepatitis $\mathrm{C}$ from positive results for anti-HCV antibody and HCV RNA. Among his two daughters, spouse, and six siblings, there was only a moderate hyperbilirubinemia in his older sister.

Mutational analyses

\section{$m R N A$ analysis}

Total RNA was extracted from peripheral white blood cells with an Isogen WB kit (Wako Pure Chemicals, Japan), and cDNA was obtained by reverse transcription of $1 \mu \mathrm{g}$ RNA with M-MLV transcriptase, RNase inhibitor (RNaseOUT, Invitrogen, Carlsbad, Calif.), and random hexamer primers (Invitrogen). Polymerase chain reaction (PCR) was performed with Taq DNA polymerase (Promega, Tokyo, Japan) and twelve primer sets originally reported by Wada et al. (1998). PCR products were separated on a $1.5 \%$ agarose gel by electrophoresis and directly sequenced by a Sequencing High detection kit (Toyobo, Tokyo, Japan).

\section{Genomic DNA analysis}

Genomic DNA was isolated from peripheral white blood cells with a DNA isolation kit (Puregene Blood Kit, Gentra Systems, Minneapolis, Minn.) and used for PCR amplification of 32 exons with flanking intronic regions by the primer sets reported by Toh et al. (1999). Direct sequencing analysis was performed by ABI PRISM Dye Terminators in an ABI 3700 Genetic Analyzer (Applied Biosystems, Foster City, Calif.).
Segregation of a novel mutation within the family

A mismatch primer set was used for the novel mutation site. The primers used to detect the mutation were the forward primer 5 '-gataggccetgtcggctctC-3' (the underlined sequence indicates the mismatched site) and the reverse primer 5'-gggaaggagaatcacagtccaca-3'. PCRs were conducted with 30 cycles of $30 \mathrm{~s}$ denaturation at $95^{\circ} \mathrm{C}, 30 \mathrm{~s}$ anneraling at $66^{\circ} \mathrm{C}$, and $30 \mathrm{~s}$ extension at $74^{\circ} \mathrm{C}$. PCR products of $234 \mathrm{bp}$ were detected by electrophoresis on a $1.5 \%$ agarose gel.

Restriction analysis of polymorphisms

Following the identification of the $-24 \mathrm{C} \rightarrow \mathrm{T}$ polymorphism in exon 1 by sequence analysis, restriction analysis with $B b s \mathrm{I}$ (New England Biolabs, Beverly, Mass.) was performed to detect this polymorphism according to the method of Mor-Cohen et al. (2001). Exon 1 was amplified by using a reported primer set (Toh et al. 1999); the product was digested by $10 \mathrm{U} \mathrm{BbsI}$ for $12 \mathrm{~h}$ at $37^{\circ} \mathrm{C}$ and separated on a $1.5 \%$ agarose gel.

\section{Results}

Mutational analysis of the MRP2 mRNA from three DJS patients revealed two types of deletion mutation, c.2272del168 and c.1901del67, which were previously known as shown in Table 1.

In the study of DJ1, the homozygous mutation c.2272del168, which causes skipping of exon 18, was detected by PCR of the MRP2 cDNA by using primer set $G$ (forward: 5'-ggagatttggctgagattggagaga-3', reverse: 5'-cttcagatgcctgccattggaccta-3') designed by Wada et al. (1998), and which covers c.2245-2608, and by direct sequencing of the PCR product (data not shown). The two daughters (DJ1/C1 and DJ1/C2) of DJ1 were heterozygous for this mutation (Table 2).

In the case of DJ2, a homozygous mutation of c.1901del67, which causes skipping of exon 15, was revealed by PCR amplification by using primer set E (forward: 5'-accttcattcagagaccaag-3', reverse: 5'ggctgatatcaaggaggatt-3') as shown in Fig. 1A. One daughter and one of two siblings of DJ2 were heterozygous for this mutation (Table 2).

In the case of DJ3, as shown in Fig. 1A, the patient was heterozygous for c.1901del67; this result was supported by sequence analysis of exon 15 with the flanking intronic region, which revealed the $1967+2 \mathrm{~T} \rightarrow \mathrm{C}$ mutation of the splicing site (Fig. 1B). In addition, sequencing analysis of exons 16 and 1 detected a novel missense mutation of $2026 \mathrm{G} \rightarrow \mathrm{C}(\mathrm{G} 676 \mathrm{R})$ in the first Walker A motif (Fig. 2) and a single nucleotide polymorphism (SNP) of $-24 \mathrm{C} \rightarrow \mathrm{T}$ in the non-coding region of exon 1 (Fig. 3). The c.1901del67 mutation was detected in two other siblings and two daughters of DJ3. Mismatch PCR revealed that the $2026 \mathrm{G} \rightarrow \mathrm{C}$ mutation was not distributed in the six siblings and two children (Table 2, Fig. 4). With respect to the polymorphism $-24 \mathrm{C} \rightarrow \mathrm{T}$, we also employed a restriction enzyme assay with $B b s \mathrm{I}$; the results showed that his spouse and one daughter were heterozygous for this SNP, but other 
Table 2 Mutations of the MRP2 gene in DJS patients and family members (wild wildtype, $n d$ not determined)

\begin{tabular}{|c|c|c|c|c|c|}
\hline \multirow{2}{*}{$\begin{array}{l}\text { Patients and } \\
\text { family } \\
\text { members }^{\mathrm{a}}\end{array}$} & & \multicolumn{2}{|c|}{ Bilirubin (mg/dl) } & \multirow[t]{2}{*}{ Alteration in MRP2 gene } & \multirow[t]{2}{*}{ Predicted effects } \\
\hline & & Total & Conjugated & & \\
\hline \multirow[t]{3}{*}{1} & DJ1 & 2.7 & 1.8 & $2439+2 \mathrm{~T} \rightarrow \mathrm{C} / 2439+2 \mathrm{~T} \rightarrow \mathrm{C}$ & 2272del168/2272del168 \\
\hline & $\mathrm{DJ} 1 / \mathrm{C} 1$ & 0.6 & 0.2 & $2439+2 \mathrm{~T} \rightarrow \mathrm{C} /$ wild & 2272del168/wild \\
\hline & $\mathrm{DJ} 1 / \mathrm{C} 2$ & 0.6 & 0.2 & $2439+2 \mathrm{~T} \rightarrow \mathrm{C} /$ wild & 2272del168/wild \\
\hline \multirow[t]{4}{*}{2} & $\mathrm{DJ} 2$ & 3.0 & 2.4 & $1967+2 \mathrm{~T} \rightarrow \mathrm{C} / 1967+2 \mathrm{~T} \rightarrow \mathrm{C}$ & 1901del67/1901del67 \\
\hline & $\mathrm{DJ} 2 / \mathrm{S} 1$ & 0.4 & 0.1 & $1967+2 \mathrm{~T} \rightarrow \mathrm{C} /$ wild & 1901del67/wild \\
\hline & $\mathrm{DJ} 2 / \mathrm{S} 2$ & 0.5 & 0.2 & Wild/wild & - \\
\hline & $\mathrm{DJ} 2 / \mathrm{C} 1$ & 0.8 & 0.2 & $1967+2 \mathrm{~T} \rightarrow \mathrm{C} /$ wild & 1901del67/wild \\
\hline \multirow[t]{9}{*}{3} & $\mathrm{DJ} 3$ & 3.4 & 2.8 & $1967+2 \mathrm{~T} \rightarrow \mathrm{C} / 2026 \mathrm{G} \rightarrow \mathrm{C}$ & 1901del67/G676R \\
\hline & $\mathrm{DJ} 3 / \mathrm{S} 1$ & 0.8 & 0.3 & Wild/wild & - \\
\hline & $\mathrm{DJ} 3 / \mathrm{S} 2$ & 0.9 & 0.3 & Wild/wild & - \\
\hline & $\mathrm{DJ} 3 / \mathrm{S} 3$ & 0.9 & 0.3 & Wild/wild & - \\
\hline & $\mathrm{DJ} 3 / \mathrm{S} 4$ & 0.9 & 0.3 & $1967+2 \mathrm{~T} \rightarrow \mathrm{C} /$ wild & 1901del67/wild \\
\hline & $\mathrm{DJ} 3 / \mathrm{S} 5$ & 0.3 & 0.1 & Wild/wild & - \\
\hline & $\mathrm{DJ} 3 / \mathrm{S} 6$ & 1.3 & 0.6 & $1967+2 \mathrm{~T} \rightarrow \mathrm{C} /$ wild & 1901del67/wild \\
\hline & $\mathrm{DJ} 3 / \mathrm{C} 1$ & nd & nd & $1967+2 \mathrm{~T} \rightarrow \mathrm{C} /$ wild & 1901del67/wild \\
\hline & $\mathrm{DJ} 3 / \mathrm{C} 2$ & 0.7 & 0.3 & $1967+2 \mathrm{~T} \rightarrow \mathrm{C} /$ wild & 1901del67/wild \\
\hline
\end{tabular}

${ }^{\mathrm{a}} C$ child, $S$ siblings
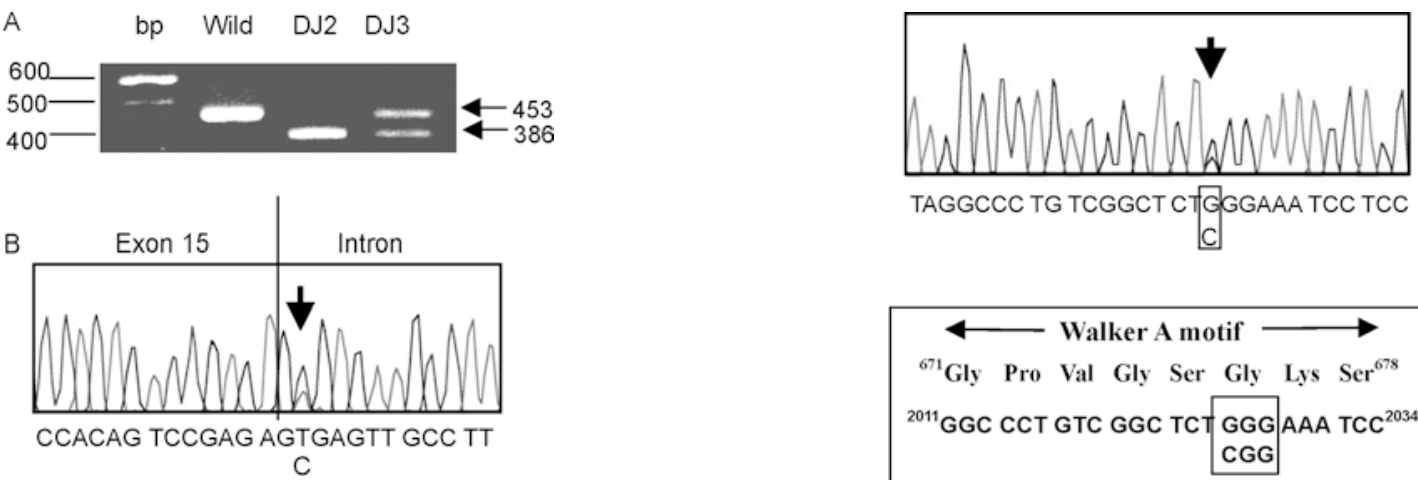

Fig 1A, B The c.1901del67 mutation found in DJ2 and DJ3. A The c.1901del67 mutation in the polymerase chain reaction (PCR) products of cDNA from DJ2 and DJ3. PCR of the cDNA from position 1597-2049 in DJ3 amplified a normal product of $453 \mathrm{bp}$ (cf. Wild) and a smaller product of $386 \mathrm{bp}$ that was confirmed to be a deletion of $67 \mathrm{bp}$ from 1901 to 1967 by sequencing analysis (data not shown). B Sequencing analysis of exon 15 in the MRP2 gene from DJ3 revealed a heterozygous point mutation at the splice site, $1967+2 \mathrm{~T} \rightarrow \mathrm{C}$ (arrow site of the mutation)

family members did not possess it (Fig. 4). There were no data for the parents and one sibling who were deceased. The new $2026 \mathrm{G} \rightarrow \mathrm{C}$ mutation was not found in 50 healthy individuals (100 alleles). These results indicated that the mutations c.1901del67 and 2026G $\rightarrow$ C were located on different alleles, and that $2026 \mathrm{G} \rightarrow \mathrm{C}$ was a disease-associated mutation. DJ3 was a compound heterozygote for these mutations.

\section{Discussion}

In the present study, we have found a novel missense mutation that is predicted to affect the substitution of glycine $^{676}$ with arginine ${ }^{676}(\mathrm{G} 676 \mathrm{R})$, together with two known deletion mutations. Glycine ${ }^{676}$ is one of the conserved amino acids (underlined) in the Walker A

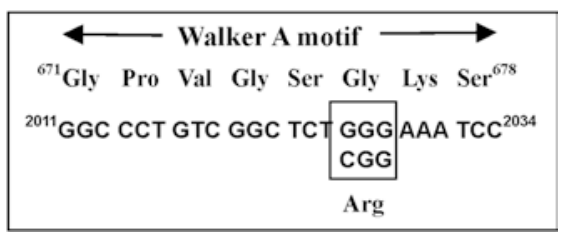

Fig. 2 Sequencing analysis of exon 16 in the MRP2 gene from DJ3 (arrow site of the heterozygous missense mutation 2026G $\rightarrow \mathrm{C}$ ). The mutation was predicted to change the amino acid sequence of the MRP2 protein from glycine ${ }^{676}$ to arginine ${ }^{676}$

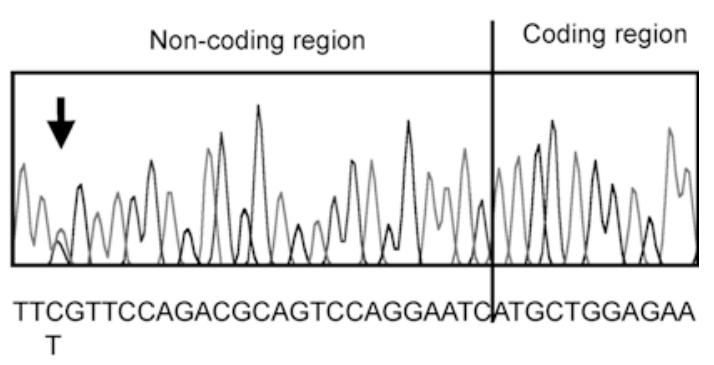

Fig. 3 The $-24 \mathrm{C} \rightarrow \mathrm{T}$ polymorphism in the non-coding region in exon 1 of the MRP2 gene from DJ3 (arrow site of the polymorphism)

motif $\left({ }^{671} \underline{G P V G G K S}{ }^{678}\right)$ in the ABC of MRP2 protein (Taniguchi et al. 1996).

Two mutations within the two ABCs in the MRP2 protein have been described previously in DJS patients in Japan as shown in Table 1. One of these mutations $(\mathrm{R} 768 \mathrm{~W})$ is located within the first Walker C motif, and the other $(\mathrm{Q} 1382 \mathrm{R})$ lies within the second ABC (Toh 
Fig. 4 Distribution of the $-24 \mathrm{C} \rightarrow \mathrm{T}$ polymorphism and the mutations c.1901del67 and $2026 \mathrm{G} \rightarrow \mathrm{C}$ in the family members of DJ3 (arrow DJ3). Insert Electrophoresis showing results of the PCR with mismatch primers for the detection of the $2026 \mathrm{G} \rightarrow \mathrm{C}$ mutation (upper mutant, lower wild-type). Left Results for the siblings of DJ3. The order is identical with the pedigree. Right DJ3 (lane 1), spouse (lane 2), and children (lanes 3, 4)

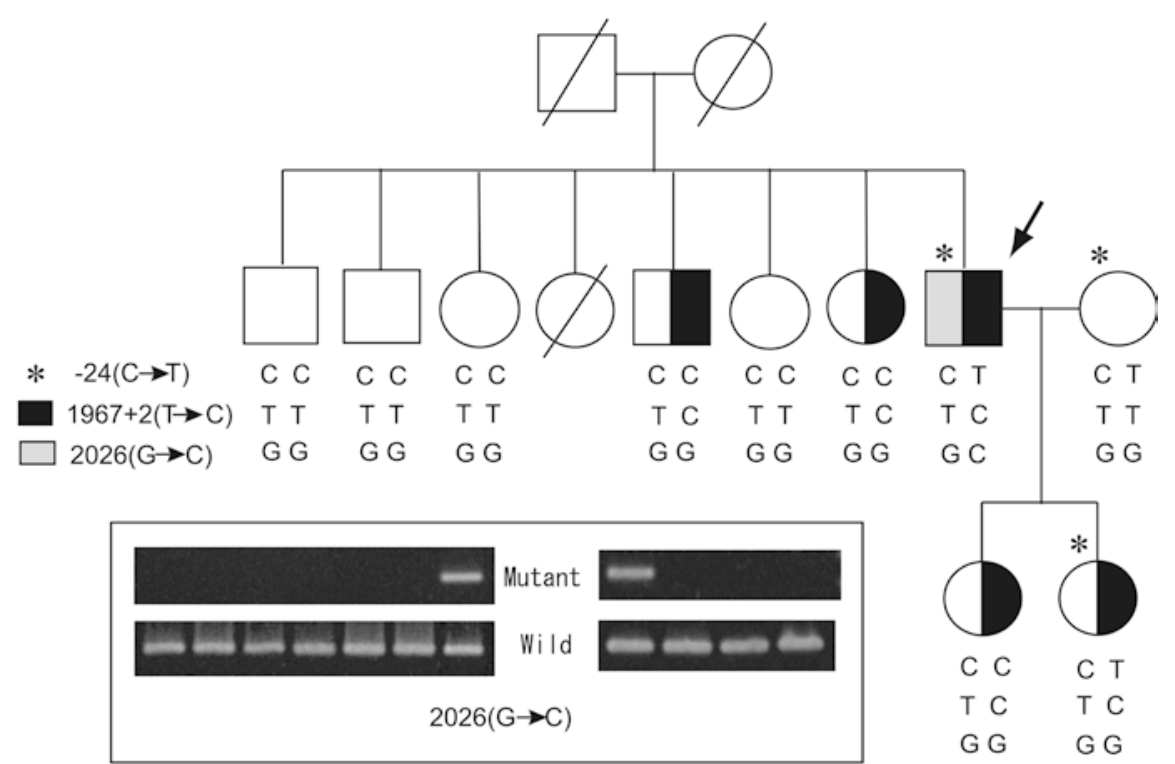

et al. 1999). The G676R conversion is the first reported mutation of the Walker A motif in MRP2 protein.

The Walker A motif consists of a sequence of eight amino acids (GPVGSGKS), and those underlined are consensus amino acids as described above. The G676R mutation is located at the 5'-flanking end of lysine, an amino acid shown to bind the $\gamma$-phosphate of ATP (Konig et al. 2003) in NBD1. In the MRP1 protein, which is a member of the same family as MRP2, the substitution of lysine with methionine in NBD1 decreases ATP-binding to NBD2 and diminishes the transport activity of the protein (Gao et al. 2000; Hou et al. 2002). In the transporters associated with antigen processing (TAP1 and TAP2), the conversion of lysine to methionine in the Walker A motif has been shown to cause a loss of transport activity (Lapinski et al. 2001).

Hashimoto et al. (2002) have reported that the artificial mutation K677R of the MRP2 gene and the missense mutation $\mathrm{R} 768 \mathrm{~W}$ cause deficient maturation and impaired sorting.

The G676R mutation is associated with a change of hydrophobicity and electronic charge. It has been speculated that G676R causes two basic amino acids, arginine and lysine, to interact and/or a change in the conformation of NBD1. The local changes in NBD1 attributable to this mutation may cause impaired expression of the MRP2 variant or may decrease the function of the two ABCs and the transport activity of the protein. From the segregation analysis of the two mutations and the $-24 \mathrm{C} \rightarrow \mathrm{T}$ polymorphism shown in Fig. 4, the segregation of c.1901del67 and $-24 \mathrm{C} \rightarrow \mathrm{T}$ in DJS3 and his family members demonstrates that these two variations were transferred independently. Thus, these two variants were on different alleles in DJS3, and $-24 \mathrm{C} \rightarrow \mathrm{T}$ was on the $2026 \mathrm{G} \rightarrow \mathrm{C}$ variant allele. This was supported by the absence of $-24 \mathrm{C} \rightarrow \mathrm{T}$ in siblings without the $2026 \mathrm{G} \rightarrow \mathrm{C}$ mutation.
Because the parents and one sibling were deceased, the genetic route and correct segregation of the G676R mutation remain unclear. Further investigation of the siblings of the parents and their family members may indicate whether this mutation is genetically transferred.

In conclusion, a novel disease-associated mutation, $2026 \mathrm{G} \rightarrow \mathrm{C}$, which is predicted to cause a G676R conversion in the MRP2 protein, has been detected in a DJS patient. This mutation is located within the first Walker A motif in the MRP2 protein.

Acknowledgements This study was supported by a Grant-in-Aid for Scientific Research (12672229) from the Ministry of Education, Science, Sports, and Culture, Japan, and the Specific Research Fund of Hokuriku University.

\section{References}

Gao M, Cui HR, Loe DW, Grant CE, Almquist KC, Cole SP, Deeley RG (2000) Comparison of the functional characteristics of the nucleotide binding domains of multidrug resistance protein 1. J Biol Chem 275:13098-13108

Hashimoto K, Uchiumi T, Konno T, Ebihara T, Nakamura T, Wada M, Sakisaka S, Maniwa F, Amachi T, Ueda K, Kuwano M (2002) Trafficking and functional defects by mutations of the ATP-binding domains in MRP2 in patients with DubunJohnson syndrome. Hepatology 36:1236-1245

Hou YX, Cui L, Riordan JR, Chang XB (2002) ATP binding to the first nucleotide-binding domain of multidrug resistance protein MRP1 increases binding and hydrolysis of ATP and trapping of ADP at the second domain. J Biol Chem 277:5110 5119

Kajihara S, Hisatomi A, Mizuta T, Hara T, Ozaki I, Wada I, Yamamoto K (1998) A splice mutation in the human canalicular multispecific organic anion transporter gene causes Dubin-Johnson syndrome. Biochem Biophys Res Commun 253:454-457

Konig J, Nies AT, Cui Y, Keppler D (2003) MRP2 the apical export pump for anionic conjugates. In: Holland IB, Cole SPC, Kuchler K, Higgins CF (eds) ABC proteins: from bacteria to man. Academic Press, London San Diego, pp 423-443 
Lapinski PE, Neubig RR, Raghavan M (2001) Walker A lysine mutations of TAP1 and TAP2 interfere with peptide translocation but not peptide binding. J Biol Chem 276:7526-7533

Mor-Cohen R, Zivelin A, Rosenberg N, Shani M, Muallem S, Seligsohn U (2001) Identification and functional analysis of two novel mutations in the multidrug resistance protein 2 gene in Israeli patients with Dubin-Johnson syndrome. J Biol Chem 276:36923-36930

Paulusma CC, Bosma PJ, Zaman GJ, Bakker CT, Otter M, Scheffer GL, Scheper RJ, Borst P, Oude Elferink RP (1996) Congenital jaundice in rats with a mutation in a multidrug resistance-associated protein gene. Science 271:1126-1128

Paulusma CC, Kool M, Bosma PJ, Scheffer GL, Borg F ter, Scheper RJ, Tytgat GN, Borst P, Baas F, Oude Elferink RP (1997) A mutation in the human canalicular multispecific organic anion transporter gene causes the Dubin-Johnson syndrome. Hepatology 25:1539-1542

Taniguchi K, Wada M, Kohno K, Nakamura T, Kawabe T, Kawakami M, Kagotani K, Okumura K, Akiyama S, Kuwano M (1996) A human canalicular multispecific organic anion transporter (cMOAT) gene is overexpressed in cisplatin-resistant human cancer cell lines with decreased drug accumulation. Cancer Res 56:4124-4129
Tate G, Li M, Suzuki T, Mitsuya T (2002) A new mutation of the ATP-binding cassette, sub-family $\mathrm{C}$, member 2 (ABCC2) gene in a Japanese patient with Dubin-Johnson syndrome. Genes Genet Syst 77:117-121

Toh S, Wada M, Uchiumi T, Inokuchi A, Makino Y, Horie Y, Adachi Y, Sakisaka S, Kuwano M (1999) Genomic structure of the canalicular multispecific organic anion-transporter gene (MRP2/cMOAT) and mutations in the ATP-binding-cassette region in Dubin-Johnson syndrome. Am J Hum Genet 64:739746

Tsujii H, Konig J, Rost D, Stockel B, Leuschner U, Keppler D (1999) Exon-intron organization of the human multidrugresistance protein 2 (MRP2) gene mutated in Dubin-Johnson syndrome. Gastroenterology 117:653-660

Wada M, Toh S, Taniguchi K, Nakamura T, Uchiumi T, Kohno K, Yoshida I, Kimura A, Sakisaka S, Adachi Y, Kuwano M (1998) Mutations in the canilicular multispecific organic anion transporter (cMOAT) gene, a novel ABC transporter, in patients with hyperbilirubinemia II/Dubin-Johnson syndrome. Hum Mol Genet 7:203-207 